\title{
7. Conclusion: Telefilm, Cross-Media Migration, and the Demise of the Film Serial
}

\begin{abstract}
The conclusion offers an outlook past the 1940s. It places film serials in the context of the shifting cinema landscape in the 1940s and 1950s and the rise of television. The chapter compares the viewer address of film serials to television's programming in terms of a 'segmented flow' and argues that film serials imagined and practiced a televisual mediality before the advent of TV. Serials and television thus became convergent media, which counters the prevalent notion that television killed film serials. The chapter further stresses the adaptability of the film-serial form to varying exhibition and distribution contexts, which helps to explain their continuous reappearance in the multiple 'new media' in the second half of the twentieth century and in the digital culture of the twenty-first century.
\end{abstract}

Keywords: television programming, televisual flow, post-WWII film history, independent film production

The present moment is an arbitrary one to end a study of film serials. Although the heyday of their production is well in the past, serials that were thought to be lost continue to reappear in archives or in private collections. Online fan groups like the serialsquadron.com offer increasing numbers of serials on DVD. Other enthusiasts make them available on youtube or upload them to archive.org, and scholars like Richard Koszarski are making an effort to locate 'new' film serials. In the final months of writing, for instance, Pathe's The House of Hate (1918) was located in Russia, digitalized, and translated back into English. Sixty years after the termination of film serial production, the number of available serials of both the silent and the sound

Brasch, I., Film Serials and the American Cinema, 1910-1940: Operational Detection, Amsterdam University Press, 2018.

DOI: $10.5117 / 9789462986527 / \mathrm{CHO} 7$ 
eras is steadily increasing, forcing me to end this study in medias res. This is not the only reason why plenty of serials have been bypassed in this study. A few were outside the scopes of the focus on crime stories; others were left out because I concentrated on American serials. More generally, even the library of film serials available today exceeds any single book-length investigation. Serials that particularly warrant further analysis include The Flame Fighter (Rayart, 1925) and The Tiger's Shadow (Pathe, 1928), of which numerous episodes are available at UCLA's Film and Television Archive, and The Chinatown Mystery (Trem Carr, 1928), which has been fully restored at George Eastman House but is not available for home viewing. These serials could further enrich our understanding of film serial production and style in the 1920s and help work towards a more complete understanding of American film immediately before the Great Depression. Additionally, some sound-era serials that are available on DVD need to be considered, such as Holt of THE SECret SERviCE (Columbia, 1941), which differs from other serials in its more definitive adult appeal. These and other serials all warrant their own close readings, but they could also enrich studies that take a look at a variety of filmic forms or cultural texts without limiting themselves to serials.

Instead of embracing the full scope of available film serials, the preceding pages have neglected quantity in favor of depth of analysis. I have anecdotally zoomed in on specific serials, episodes, scenes, and their release contexts in order to outline their distinct mode of storytelling and mode of address. As I have detailed, film serials reach out to their viewers both through their demonstrative, presentational address and by encountering viewers in their daily lives, in newspaper novels and magazine stories, in comic strips, in radio programs, through 'street ballyhoo', and in other ad campaigns seeking to transform cinema lobbies and the main streets of rural towns according to a particular serial's narrative world.

Many film serial plots are about masked villains to be identified, criminal gangs to be dismantled, murders to be retaliated, scientific codes to be retrieved, and genius inventions to be protected. Therefore, even when they do not self-identify as detectives, heroes of film serials more often than not set out to recover and correlate, to trace and to bring to justice the evil and greedy lawyers, scientists, archaeologists, or otherwise dubious characters undermining society. This focus on crime, mystery, and acts of uncovering harkens back to an interest in detective plots and in new technologies that markedly informed American popular culture from the 1840 s onwards. Many serials are fascinated with factual or imagined technological contraptions, and they often foreground and demonstrate the machinic quality of film 
itself, that is, its technological orchestration of correspondences between images, objects, and spaces. This showcasing of cinematic creation effects a presentational mode of address that demonstrates processes of and approaches to storytelling while itself telling a story. In short, a film serial narrative simultaneously serves as an example and as its explanation.

The multifaceted operational aesthetic of film serials combines elements that surface in the nineteenth century in evaluations of publicly displayed technologies and curious objects, in the questioning of possibly deceptive journalism, but also in the descriptions of cause and effect in magazine explanations of technical mechanisms or in the analytic storytelling of detective fiction. However, as I have shown, instead of solely inviting viewers to retrospectively marvel at a given detective's genius, serials are radically presentist: they establish each step in the narrative as taking place now and the overall hunt for the master villain as not yet terminated. They offer up each anecdotal story element as one piece in a yet unfulfilled chain of cause and effect that viewers watch as it propels along. The episodes deliver clues to the case, whether relevant or not, to the viewers, who emerge as detectives who correlate information and establish connections as the narrative unfolds. In opposition to carefully constructed detective stories, film serial narratives do not choose a straight path from problem to resolution from all the routes the story could possibly take. Instead of practicing reduction and narrative integration, serials embrace a great variety of contingent story elements to an extent that exceeds that of many other cultural products, such as detective stories in print and on film. Importantly, as I hope I have shown, the distinct characteristics and mode of address of the film serial was not a short-lived detour in Hollywood history. Instead, film serials arose alongside the feature film, from the same breeding ground of transitionalera filmmaking, and both forms coexisted for more than forty years. The significance of this alternative mode of filmmaking, however, only surfaces from an analysis and a historiography that takes into account both silent- and sound-era serials, suspending the division of the study of film serials into two separate realms of film scholarship.

Film serials are part of a broader field of popular-cultural production and consumption that includes Hollywood's release of B-fare, shorts, and animated films, but also radio programs, serials and comics in newspapers and in their Sunday supplements, and the narratives in pulp magazines and low-cost novels. When commercial television began to bring moving image entertainment to American living rooms in the 1940s and 1950s, the broadcasted programs soon adapted material from this multifaceted popular-cultural field. Therefore, rather than exclusively considering film 
serials as part of American silent- and studio-era film production, the following pages place the demise of film serial production within the context of a televisual mode of viewer address. I will briefly outline the conflicted relationships of film studios with the production of television programs at a time when television shifted from airing live content to recorded material. Drawing on studies of television by Raymond Williams and Jane Feuer, I will then show how television's mode of address resembles the viewer address of film serials, making TV the perfect platform for similar content. Thus, whereas the production of film serials proper ended in the mid-1950s, television tapped into a film reception culture that had been part of cinema for decades. Simultaneously, as I will show, film serials refused to vanish into oblivion after their heydays. From the 1960s until today, the serial has demonstrated its adaptability to varying technological transformations by participating in media change, inscribing itself into television programs in the 196os and 1970s, reappearing on VHS in 1980 os and 1990s, on DVD around the millennium, and by thriving in today's online sharing culture.

\section{Media and Forms, Serials and Television}

1956 marked the end of the production of film serials. From the mid-1930s onwards, production had been almost exclusively in the hands of Universal, Columbia, and Republic. Universal terminated its serial output after its 1946 releases - a move that a New York Times article at the time believed would cause 'murmuring in the suburbs' because 'serials are the life-blood of nearly half of this country's approximately 21,000 theatres' (Hurst 2007: 146-147). Republic continued until 1955, ceasing production one year prior to Columbia's release of the final American film serial, BLAZING THE OvERLAND TrAIL. The demise of the film serial is typically seen as a more or less direct result of the consolidation of the television industry and the increasing availability of televised entertainment. J.P. Telotte, for example, attributes the death of the serial to shifting patterns of film distribution and film viewing, but also to TV (1995: 92). Similarly, Scott Higgins stresses that sound serials targeted a juvenile audience that found equally apt entertainment on television, the programming of which integrated serialized adventures more readily into the scheduling of daily life (2016:180). While also attributing the end of film serial production to television, Richard M. Hurst adds that rising costs of film production after World War II and the resulting reduction in writing and production staff brought about less innovative and more cheaply produced film serials with shorter, qualitatively inferior episodes - a shift 
that contributed to the form's demise (p. 145; see also Telotte 1995: 110). Without neglecting the immediate relation of the large-scale dissemination of television and the demise of the film serial in the 1950s, I argue that television offered a mode of viewer address that film serials had promoted throughout their more than four decades of existence. As I will briefly outline below, television's threat to film serials results not only from its placement in the home but from the fact that televisual programming with its self-ascribed liveness adopted a similarly presentist and presentational approach to storytelling as the one serials had propagated since American cinema's transitional era.

Serials hailed the advent of TV for more than a decade. Yet the live medium they imagined only existed for a short period — until the early 1950s. As chapter six illustrates, film-serial portrayals of television shifted from depictions of television in terms of sci-fi contraptions to TV as a live-broadcast medium in the 1930s and 1940s. The queen of the underground civilization in The Phantom Empire (Mascot, 1935), for example, uses television to surveil proceedings on the surface of the earth, whereas the masked villain of SPY SMASHER (Republic, 1942) operates a television channel as a front to place surveillance cameras in the offices of a military official. Although they cast television respectively as a futuristic fringe technology and a proto-factual broadcast medium, both serials highlight TV's capacity to transmit live images. And television was indeed live during its first years.

Adopting its programming strategy from radio, during the $1940 \mathrm{os}$ and into the 1950 s television sold broadcasting time to advertising agencies who contributed live content (Anderson 1994: 6). However, aiming to increase control over their programming, TV channels introduced commercial breaks and began to air their own live shows (Boddy 1985: 27). By 1950, TV sought cooperation with Hollywood to create original content while reducing the financial risks of film production (Anderson 1994: 6). This collaboration resulted in a steady decrease in live programming in favor of recorded forms and practically ended television's era of live entertainment, shifting from the "Golden Age" of live anthology drama' to what some contemporaneous critics, according to William Boddy, perceived as the "'vast wasteland"' of 'studio-produced action-adventure series of the late 1950s' (1985: 23; see also Anderson 1994: 7; Boddy 1985: 29; Schatz 1998: 463-481). In line with early television's continuation or adaptation of radio programming, such critics equated liveness with quality (cf. Hilmes 1997: 50; see chapter 6 of this volume).

Serials had similarly envisioned television to be a live medium. In fact, their tendency to stress liveness in their portrayals of TV may have 
eliminated concerns that television could become cinema's rival. Nevertheless, individual serials simultaneously seemed to suspect that future appearances of their protagonists would take place on television rather than on cinema screens (Mayer 2014: 98). ${ }^{1}$ Serials thus both celebrated live television and acknowledged the medium's threat to replace weekly serialized film. And indeed, serial favorites such as Dick Tracy or The Lone Ranger appeared on TV in the 1950s (Hurst 2007: 148). Whereas the shared heroes of film serials and television shows often originated in comics and radio programs, individual television shows particularly referenced the film serials by shooting in the same locations-examples include THE LONE RANGer (ABC, 1949-1957), SUPERMAN (syndicated, 1952-1958), or FlASH GoRDON (syndicated, 1954-1955) (Higgins 2016: 180). More generally, many telefilm series of the 1950s offered sequences of action and violence that resembled the appeals of film serials but packaged them in self-contained half-hour episodes (p. 180).

This redistribution of content between cinema and television co-occurred with a larger transformation of the Hollywood film industry. Facing post-war economic changes and the effects of the 1948 Paramount decree, ${ }^{2}$ television became a convenient stock villain for the major studios, especially since antimonopoly regulations limited their influence on the new entertainment market (Anderson 1994: 2; see also Schatz 1998: 472). ${ }^{3}$ The studios that produced film serials - Columbia and Universal, who ran medium-size studios without attached theater chains, and Republic, a producer of B-fare without cinema ownership—profited from the 1948 court decision because it terminated block-booking practices that disabled the screening of film serials in many urban theaters, relegating them to suburban and rural, mostly independent theaters that had nevertheless sustained the form throughout the decades. As the majors were thus prohibited from forcing exhibitors to buy their B-fare along with their quality features, Hollywood's

1 Mayer's argument is based on her reading of Republic's 1940 serial THE Drums of Fu MANCHU. In fact, Fu Manchu debuted on TV in The Adventures of FU MANCHU in 1956. The series was produced by the Hollywood Television Service, a company that was founded by Republic in $195^{\circ}$ and outlived the film studio (Hurst 2007: 221; Mayer 2014: 98).

2 At the time, the Supreme Court decision forced the vertically integrated majors to sell large amounts of their theaters, which, in concert with subsequent court decisions, inaugurated a transformation process that continued throughout the 1950s (Anderson 1994: 6; Boddy 1985: 24). 3 The Federal Communications Commission (FCC), originally the governmental institution to regulate radio, now oversaw the commercial television market. Fearing that the majors would continue their control over film distribution by replacing their theater chains with television channels, the FCC blocked the studio's purchasing efforts in order to avoid the continuation of monopolies (Schatz 1998: 472). 
largest studios discontinued much of their low-budget production, making room for previously constrained smaller producers (Schatz 1998: 340-341). However, decades of practice in cost- and time-efficient filmmaking had prepared these smaller studios for telefilm production (p. 473). Instead of embracing new theatrical screening venues, these studios turned to television as their exhibition outlet (Anderson 1994: 2-3). As a consequence, film studios discontinued most of their B-fare production, while newly formed companies produced content for TV (cf. Anderson 1994: 6; Boddy 1985: 25; Schatz 1998: 464).

In the context of the large-scale transformation of Hollywood that followed the governmental dismantling of the monopolistic studio system, it is arguable whether the continuous production of generic, low-cost content ended because of television, or whether television picked up on popularcultural forms that cinema had discarded and left up for grabs. Either way, television offered an ideal outlet for formulaic, B-production film. Not only the heroes and attractions of film serials migrated from cinema to television but also large parts of Hollywood's poverty-row or B-film culture. The result of this radical transformation of Hollywood production culture was a redistribution of forms among the media, to use Niklas Luhmann's terms (see chapter 6 of this volume). Television did not kill cinema, yet it adopted its forms. A return to Luhmann's distinction helps to describe this shift. As a medium, cinema functions as a container for particular forms, including the film serial but also for instance feature films, comedies, or newsreels. Television assumes a similar function, and the visual forms of both media become in a way detachable from their media-institutional breeding grounds. After television's early live phase - that is, as soon as TV began to show filmed material often referred to as 'telefilm'-both cinema and television became different media with the capacity to house the same forms.

In a way, the film studio RKO had anticipated this migration of forms in 1944 (importantly, before the Paramount decree) when, in response to exhibitors' threats to boycott studios that invested in and produced for television, they released a statement arguing that 'it would seem to be in the best interests of the entire motion picture industry that production-distribution companies should participate in television, not only to protect themselves but exhibitors as well, by directing television programming into fields which would be far removed from feature films created for the theatre' (quoted in Boddy 1985: 25). RKO thus campaigned for a cultural construction of television that would render its broadcasting of cinematic film inappropriate and thereby suspend TV's capacity to host cinematic forms. Despite such 
efforts, television's technological capacity to broadcast telefilm was never effectively countered by opposing discursive ideals. As Elena Esposito has outlined following Luhmann's approach, audiences experience and define a given medium through its forms (see chapter 6 of this volume). Considered in this way, both cinema and television reinvented themselves in the 1950s through their efforts to both cooperate and differentiate, as both media are defined by the forms they offer to their audiences.

Television as it evolved after its early live phase drew on a mode of address that similarly informed film serials as they have been described throughout the preceding chapters. In fact, the concepts analyzed in this volume-film serials' presentism and presentationalism outlined in chapter three; the repetitions, reiterations, and reenactments explained in chapter five; and film serials' juxtaposition of multiple forms and modes of address and their imagined liveness examined in the penultimate chapter-seem to find correspondences in the field of television studies. Jane Feuer stresses that when television embraced prerecorded forms in the 1950s, it nevertheless retained its sense of presence because of its insistence on the simultaneity of transmission and viewing. The synchronicity of an event and its broadcast transmission gave way to TV's enduring 'ideology of the live, the immediate, the direct, the spontaneous, the real. This is true of both program formats and metadiscourse' (Feuer 1983: 14). ${ }^{4}$ Television thus ascribed a notion of liveness to its collage of recorded material just like film serials of the sound era did-most particularly in THE PHANTOM EMPIRE with its diegetic radio broadcast. For Feuer, television's insistence on liveness was a means to integrate the fragmented elements of the TV program, with its news reports, interview sections, clips, commercials, trailers, and segmented narratives into what Raymond Williams has famously termed the televisual 'flow' (p.16). Williams employs the term to describe a shift from the programming of discrete units towards a broadcast model that offers a continuous flow of short elements like commercials, trailers, and parts of series without marking the transition between elements, and without connecting, comparing, or contrasting these elements (R. Williams 2004: 89-92, 118). ${ }^{5}$ Feuer adopts his notion of flow as it elucidates TV's suggestion of immediacy and presence,

4 Feuer in this passage draws on work by Stephen Heath and Gillian Skirrow (1977).

5 Writing during the 1970s, Williams contends that these elements are particularly short in American television programming (R. Williams 2004: 74). Interestingly, Williams himself locates a similarly interrupted viewing experience in cinema's inclusion of shorts and double bills or 'B'-films that, 'with appropriate intervals for advertising and for the planned selling of refreshments, began to develop the cinema towards the new kind of planned flow' (p. 91). Although he thus admits that cinema worked similarly, he overlooks the history of the practice, 
but she stresses that television hinges on a dialectic of segmentation and flow, on 'segmentation without closure' (1983: 16). Although the flow of $\mathrm{TV}$ promises to continue endlessly, viewers are aware of its segmentation, especially when individual television programs begin or end for the day (cf. Kompare 2006: 340).

Film serials exist at a comparable nexus of segmentation and flow: although individual serials ended after a previously determined number of episodes, the three studios producing serials during the sound era each scheduled their output in a way that ensured the continuous supply of an episode a week throughout the year (cf. Higgins 2016: 5). Moreover, what I have referred to throughout the preceding chapters and particularly in chapter four as operational detection resembles television viewers' activity of correlating segments. More often than not, the connection or contrasting of elements bypasses the chronology of segments as they follow one another in TV's endless flow. Through practices of repetition and variation, individual segments establish themselves as part of a series and thereby invite a correlation with previous installments. Viewers quite obviously connect today's installment of a soap opera with yesterday's, and they similarly correlate, for example, today's weather forecast and yesterday's. Comparable correlative efforts apply to formula, when viewers contrast the narrative organization of the episodes of one cop show with another, or when they recognize similar plot twists in two different soap operas. In addition to identifying repetition and correlating comparable segments, viewers thus identify cultural anecdotes even within the segments of the ongoing flow. This mode of reception relates to the viewers' awareness of the operational aesthetics of TV, that is, of the recurring patterns that determine both the organization of television programming and the narrative formulae of particular shows.

In this process, every following segment or anecdote is encoded as 'new' and is integrated 'live' into the ongoing narrative and flow. ${ }^{6}$ John Fiske ascribes a similar task of live correlation to television viewers, and he considers this task a means of empowerment:

as especially the early Nickelodeon culture offered a kind of flow that resembles television much more than studio-era exhibition practices.

6 Lorenz Engell holds that repetition and variation - that is, the question of whether information in a given television program is coded as 'old' or 'new'-is not a quality inherent to that information but an attribute that is given in the moment it appears. Referencing the 'and-now' structure of television, Engell stresses that this 'operational memory', that is, the act of deciding whether something is old or new, always takes place according to the present needs of a program (2011: 117-120). 
Television's “now-ness" makes suspense seem real, not manufactured, and invites the viewer to "live" the experience of solving the enigma, rather than be told the process of its already achieved and recorded resolution. The story appears to be happening now, its future to be still unwritten. So in soap opera, in sport, in quiz shows, the hermeneutic code is more imperative, the engagement it requires is more "equal", for both narrative and viewer appear to be equally lacking in knowledge as they live through the enigma's resolution. This is a more engaged and empowering reading relation than that offered by the novel or by film. (1987: 145)

Incidentally, Fiske's description itself invokes a vocabulary of mystery and detection ('solving the enigma') although he does not focus on detective series. Viewers, it seems, approach television in general in ways that resemble the engagement with detective stories that are not told in retrospect. TV's liveness is, on the one hand, a self-ascribed quality that results, for instance, from the pre-commercial break promise that the show will be 'right back'. On the other hand, seriality and the integration of interrupted narratives into the viewer's personal schedules suggests the simultaneous unfolding of televised stories alongside a viewer's own perceived passage of time. Serialized detective stories and serial narratives more generally thrive on fragmentation, on the breaks and disruptions that necessitate but also enable the viewers' efforts at operational detection. In film serials, this fragmentation not only results from their separation into weekly units, but each episode itself consists of anecdotal elements, with breaks that the serials refuse to suture. From weekly returning features such as the plot recap and the cliffhanger to the formulaic arrangement of narrative and action sequences, the return of anecdotal micro-plots, the inclusion of repeat or library footage, down to foregrounded cuts between individual shots, serials present fragments for correlation that resemble television's segmented flow.

Similar to Fiske's claim that the act of watching television is more 'engaged and empowering' than film viewing (1987:145, see above), Williams and Feuer occasionally reference cinema as the antithesis of televisual flow (R. Williams 2004: 91; Feuer 1983:15). Feuer, for instance, argues that in television, 'unlike narrative cinema, segmentation is already a property of the text' (p. 15). It is at this point that my previous analysis of film serials offers an intervention, as film serials are particularly segmented and fragmented, but they are nevertheless narrative forms of cinema. Serials thus preempt a shift that Miriam Hansen describes for the difference of television and cinema, when she argues that 
the spatio-temporal configuration of television within the domestic environment has broken the spell of the classical diegesis; the compulsive temporality of public projection has given way to [...] distracted and fragmented acts of consumption. As critics have observed, an aesthetics of the "glance" is replacing the aesthetics of the "gaze", the illusionist absorption of the viewer that is considered one of the hallmarks of classical cinema. ${ }^{7}(1993: 198)$

Both film serials and television offer highly fragmented entertainment, and they evoke a sense of liveness to counteract segmentation. In film serials, the seams or gutters never disappear. Instead, serials exhibit and showcase the ruptures between fragments in ways that encourage operational detection.

As chapter five has shown, repetition, reiteration, and reenactment identify parts of a serial as anecdotal and ripe for correlation. In this context, anecdotes are segments that mean something in correlation to other segments, for instance shots that we have seen before, narrative strategies that recur at a particular point of each episode, or plot developments that have happened before in a comparable way. The arrangement of anecdotes relies on multiple forms of serialization, as anecdotal elements recur each week or warrant comparison outside of the scheduled chronology of the order of episodes. Feuer's analysis of the coverage of the 1980 Olympics on American television, which is at the heart of her argument, reveals a similarly serial organization. The coverage often cut back and forth between sports being pursued simultaneously, it included sequences of narrative commentary, sped up contests in time-lapse editing, or repeated sequences in slow motion. The segments of the coverage of the games thus similarly repeated sequences, returned to a game left off earlier, and connected all elements through the suggested liveness of the broadcast (Feuer 1983: 16). In arranging repeated and varying anecdotes within a context of supposed liveness, television employs a narrative strategy and mode of address from which film serials had profited decades earlier. In whatever way the demise of film serials and the rise of television interrelate, serials did employ a mode of address that television could offer similarly and probably better because it could at least reinforce its self-identification as live with reference to broadcasting. Whereas film serials offered alternative views on Hollywood's film culture before and during the studio era, they are also

7 Hansen compares the subject positions offered by television in the 1990s to early film practices, including Tom Gunning's description of early film's 'presentational style that addresses the viewer directly' and a 'more overt reliance on cultural intertexts' (1993: 200). 
part of a cultural history of forms that exceeds any individual medium. They fit into a history of serialized programs and popular-cultural modes of address across the media. Moreover, it was this cross-media appeal of the serials' viewer address that enabled their repeated integration into the changing contexts of film dissemination after the termination of film serial production.

\section{Afterlives: Media Change and the Continuous Appeal of Serials}

Although production ended in 1956, film serials never truly disappeared from popular cultural knowledge. The film serial as a form easily crossed thresholds into new media and proved its resilience throughout the multiple media changes of the second half of the twentieth century and into the twenty-first. The reasons for their continuous reappearance in various media range from a sense of nostalgia for bygone times to a search for popular-cultural origins and to more pragmatic reasons such as their ready availability for re-editing and reruns, as copyrights were often not renewed or screening rights were sold to TV channels as a part of a studio's larger backlog. Moreover, their futuristic narratives and mise-en-scène seem to have addressed themes that continued to impact cultural and political issues and awareness throughout the twentieth century. Whereas the actual footage seemed historical, the central concerns of some serials were far from out of date.

This appeal to varying cultural-historical circumstances was prefigured before the end of film serial production. In 1945, Film Daily reported that New York's World Theatre reran The Phantom Empire (Mascot, 1935) as part of a double feature in order to take 'advantage of the Atomic Bombing of Japan'. The screening was accompanied by 'a showmanship display of facts about atomic machines of destruction' in the theater lobby, which also 'called attention to the thrilling picture itself, which tells of an Electrical Empire and the Atomic defensive devices they used-a preview of what we might expect in the future' (Film Daily). This somewhat disturbing marketing strategy brackets much of what defined film serials and their operational aesthetics for decades: the focus on novel technologies, the promise to showcase their application, and the explanation of science and technology in (supposedly) educational lobby displays. In fact, a misspelled caption underneath an image accompanying Film Daily's article points to the intersection of science-fiction and reality when it refers to The Phantom EMPIRE as an 'unusual fact-action picture' (Film 
Daily). ${ }^{8}$ It seems as if the interest in atomic technology itself sufficed for the opportune rerun, despite the fact that The PhAntom EMPIRE's underground civilization destroys itself with its own atomic weapons at the end of the film. Moreover, the serial's appropriation in the immediate post-Hiroshima context exemplifies the reusability of serial plots and their diegetic technologies. Just as the 1925 serial THE POWER GoD had ascribed the possibility of its power engine to draw electricity from air varyingly to Tesla coil or atomic energy, ${ }^{9}$ the underground kingdom in The РнANтом EMPIRE uses technological marvels whose function can be attributed interchangeably to electricity, radio and television, or atomic energy. It was this ability to re-appropriate that enabled a ten-year-old serial to grant audiences a look into the future in 1945 .

The version of The Phantom EMPIRE that was shown in August 1945 in New York under the new title The ATOMIC RAIDERs re-edited the serial into a self-contained feature film. It was thus not only the variably interpretable content of the serial that rendered it appropriable for a renewed screening but also the quite tangible adaptability of film serials to changing exhibition contexts. They could be edited into features or shown serially, and episodes could be shown individually, in groups, or back to back. It was this flexibility that then informed the serials' televisual screenings.

In 1966, Film Fan Monthly offered serial fans guidance within the shapeshifting culture of film serial exhibition. The magazine welcomed the new accessibility of Republic serials from the 1930s and 1940s, which were screened by television stations throughout the United States in the form of 100-minute features. At the same time, Film Fan Monthly lamented the TV stations' favoring of features over a possible screening of full serials, and the magazine compensated for the retitling of the films by providing a list of 26 feature versions and the corresponding release titles of the original Republic serials (Davy). Whereas a majority of them seem to be genuinely new titles, the renaming of Spy SMASHER (Republic, 1942) to SPy SMASHER RETURNS suggests that the rerun self-identified as a sequel, placing the serial again at a threshold of historicity and novelty, or repetition and variation. A decade later, an article about FLASH GoRDON star Buster Crabbe homed in on the continuous interest in serials, their flexible screening options, and the sense of nostalgia that informed TV programming more generally. The article claims that millions of viewers tuned in for 'the antiquated,

8 Film Daily's article refers to the film as a 'fast-action' film, which was a more common term to describe action films and probably the intended spelling for the image caption.

9 For a detailed reading of THe Power GoD, see chapter five of this volume. 
40-year-old series' on Fridays and Sundays, with a substantial female fan base. Additionally, the TV channel WFIX-TV telecast the entire original thirteen-episode serial on 4 July 1976, between midnight and four a.m. On the one hand, the article related the renewed interest in the serial to the contemporaneous interest in science fiction that followed the popularity of shows like STAR TrEK (Gardella 1976), thus retrospectively ascribing the serial a culturally formative impact. On the other hand, the article explained TV's recycling of serials with reference to the fact that the programming chiefs of television channels at the time belonged to a generation that grew up watching them. Programmers as well as fans looked for a way to share their childhood favorites with their own children. However, the scheduling for FLASH GORDON on Sundays at eleven p.m. and the article's description of a college fan culture around Buster Crabbe suggests that the serials appealed to a more diverse audience, including viewers without personal nostalgic attachments (Gardella 1976). For audiences that were familiar with film serials, the fact that television recycled them implicitly affirmed the cultural value of a formerly ephemeral form, as Jonathan Gray describes it for TV reruns more generally (2010:64). Moreover, as Paul Grainge stresses in an essay that questions the understanding of media nostalgia in terms of a longing for a bygone past, recycling culture and nostalgia are 'the result of specific technological transformations' (Grainge 2000: 29). Television reruns, especially outside of prime-time programming, reveled in the new technological possibilities to visit or re-visit Hollywood's history.

While attracting new fans of film serials, these reruns intensified the devotion of fans for whom such serials were a part of fond childhood memories. Thus, early histories of especially the sound serials served not only as works of critical reference before the advent of the internet but doubled as nostalgic entertainment for readers who remembered seeing serials in local cinemas during their childhood (Barbour 1979; Fernett 1968; R.W. Stedman 1971). The authors of The Great Movie Serials: Their Sound and Fury, for instance, claim in a note to the reader that 'while this is primarily intended as a book of nostalgia entertainment, we believe it can also serve as a reference work' (Harmon \& Glut 1973: xix). In a way, these books corresponded to the serials' resurgence on TV, when viewers were reminded of their childhood favorites in a medium that offered a similarly fleeting form of entertainment as the cinema. Written accounts of serial actors and plots and printed film stills therefore also served to archive knowledge of a bygone cinematic tradition and allowed fans to hang on to a history that they could physically own. Alan G. Barbour's magazine the Serial Quarterly, which began publication to subscribers only in 1966 , 
should be considered in this context. For a limited amount of years, the Serial Quarterly printed episode plot summaries alongside serial posters, film stills, and other pressbook material (Barbour 1966; Barbour 1967). Like books on film serials, the magazine took up a similar function as fan magazines in the 1930s had, which, according to Kathleen Loock, 'prompted [...] readers to recognize themselves as a media generation' (2016: 130). Whereas some early authors on film serials had themselves been part of Saturday matinee audiences as children (Cline 1984: vii), later reference works were written by authors who had as children enjoyed afternoon reruns on television. These authors benefited particularly from VHS releases in the 1980 s and 199os, when independent publishers released serials that had gone into public domain (Davis 2007:11, 13).

In another generational shift, some of today's serial enthusiasts inherited their interest in film serials from the previous generation. The Serial Squadron, an archival website and forum that offers digitally restored silent- and sound-era serials on DVD, was founded in the late 1990s by Raymond W. Stedman, who authored books on serials in the 1970s, and his son Eric Stedman, who now continues the project, releasing an increasing amount of restored serials each year. Additionally, historians and fans increasingly make serials available on open streaming and downloading sites, particularly on youtube.com and on archive.org. Although they are invested in and appropriate historical moving image material, these practices are deeply embedded in 'a digital media culture that thrives on remembering, storing, and archiving Hollywood's past and present' (Loock 2016:123). As opposed to the ephemerality of cinematic screenings and televisual recycling, recording media such as VHS and DVD and later digital technologies have, as Loock stresses, 'enabled viewers to become film collectors and cultural archaeologists' (p. 133). The internet enables fans to make available vast amounts of twentieth-century moving images, it enables the formation of fan communities, and it fosters the conversion of new viewers to film serial fandom. These viewers might be driven by a family-genealogical interest in the favorite films of their parents or grandparents, they might be tracing the media histories of iconic comic heroes of their own time, or they may be more general film history enthusiasts.

The continuing popularity of film serials among fans, however small their groups may be, is part of an online culture that revels in the mediatechnological possibilities of its own time. Large archival websites align much of our popular-cultural history side by side, urging viewers to formulate personal evaluations of historical moving images instead of only providing previously culturally validated films. The current interest of 
media studies in archaeological excavations of bygone technologies and forms of entertainment thus overlaps with a more general public interest in the history of popular culture. Consumers of film serials on the internet perform their own acts of media archaeology, despite the fact that they rely on previously found and digitalized material. As I hope I have shown, similar investigations on online platforms and in traditional local archives help film scholars to reinstate some of the complexities of twentieth-century entertainment culture.

\section{Bibliography}

Anderson, Christopher. 1994. Hollywood TV: The Studio System in the Fifties. Austin: University of Texas Press.

Barbour, Alan G. 1966. Serial Quarterly.

-.1967. Serial Quarterly.

- 1979. Cliffhanger: A Pictorial History of the Motion Picture Serial. New York: Citadel.

Blazing the Overland Trail. Dir. Spencer Gordon Bennett. Perf. Norma Brooks, Dennis Moore, Lee Roberts. Columbia, 1956.

Boddy, William. 1985. "The Studios Move into Prime Time: Hollywood and the Television Industry in the 1950s." Cinema Journal 24 (4): 23-37.

Cline, William C. 1984. In the Nick of Time: Motion Picture Sound Serials. Jefferson, NC: McFarland. Davis, Hank. 2007. Classic Cliffhangers, Volume 1-3. Baltimore, MD: Midnight Marquee Press.

Davy, Daryl. 1966. "Republic Serials on TV." Film Fan Monthly, November.

Drums of Fu Manchu. Dir. William Witney, John English. Perf. Henry Brandon, Robert Kellard, William Royle. Republic, 1940.

Engell, Lorenz. 2011. “Erinnern/Vergessen. Serien Als Operatives Gedächtnis Des Fernsehens.” In Serielle Formen. Von Den Frühen Film-Serials Zu Aktuellen Quality-TV Und Online-Serien, edited by Robert Blanchet, Kristina Köhler, Tereza Smid, and Julia Zutavern, pp. 115-33. Zürcher Filmstudien 25. Marburg: Schüren.

Esposito, Elena. 2004. “The Arts of Contingency." Critical Inquiry 31 (1): 7-25.

Fernett, Gene. 1968. Next Time Drive Off The Cliff! Cocoa, Fl.: Cinememories.

Feuer, Jane. 1983. “The Concept of Live Television: Ontology as Ideology." In Regarding Television: Critical Approaches, An Anthology, edited by E. Ann Kaplan, pp. 12-21. Los Angeles: American Film Institute.

Film Daily. 1945. "Atomic Picture Bombs Broadway: Showmanship Scoop Boosts Receipts," August 22.

Fiske, John. 1987. Television Culture. London and New York: Routledge.

Flash Gordon. Dir. Frederick Stephani. Perf. Buster Crabbe, Charles M. Middleton, Jean Rogers. Universal, 1936.

Gardella, Kay. 1976. “Tide of Nostalgia Washes Buster in.” Sunday News, June 6.

Grainge, Paul. 200o. "Nostalgia and Style in Retro America: Moods, Modes, and Media Recycling." Journal of American \& Comparative Cultures 32 (1): 27-34.

Gray, Jonathan. 2010. Show Sold Separately: Promos, Spoilers and Other Media Paratexts. New York: New York University Press. 
Hansen, Miriam. 1993. “Early Cinema, Late Cinema: Permutations of the Public Sphere." Screen 34 (3): 197-210.

Harmon, Jim, and Donald F. Glut. 1973. The Great Movie Serials: Their Sound and Fury. New York: Routledge.

Heath, Stephen, and Gillian Skirrow. 1977. "Television: A World in Action." Screen 18 (2): 7-59.

Higgins, Scott. 2016. Matinee Melodrama: Play and the Art of Formula in the Sound Serial. New Brunswick: Rutgers University Press.

Hilmes, Michele. 1997. Radio Voices: American Broadcasting, 1922-1952. Minneapolis: University of Minnesota Press.

Holt of the Secret Service. Dir. James W. Horne. Perf. Evelyn Brent, Jack Holt, Montague Shaw. Columbia, 1941.

Hurst, Richard M. 2007. Republic Studios: Between Poverty Row and the Majors. Lanham, MD: Scarecrow Press.

Kompare, Derek. 2006. "Publishing Flow: DVD Box Sets and the Reconception of Television." Television \& New Media 7 (4): 335-6o.

Loock, Kathleen. 2016. “Sound Memories: 'Talker Remakes,' Paratexts, and the Cinematic Past.” In The Politics of Ephemeral Digital Media: Permanence and Obsolescence in Paratexts, edited by Sara Pesce and Paolo Noto, pp. 123-137. New York: Routledge.

Luhmann, Niklas. 1997. Die Gesellschaft Der Gesellschaft. Frankfurt am Main: Suhrkamp.

Mayer, Ruth. 2014. Serial Fu Manchu: The Chinese Supervillain and the Spread of Yellow Peril Ideology. Philadelphia: Temple University Press.

Schatz, Thomas. 1998. The Genius of the System: Hollywood Film-Making in the Studio Era. London: Faber and Faber.

Spy Smasher. Dir. William Witney. Perf. Marguerite Chapman, Sam Flint, Kane Richmond. Republic, 1942 .

Star Trek. Creator: Gene Rodenberry. Perf. DeForest Kelley, Leonard Nimoy, William Shatner. Norway Productions, Desilu Productions, Paramount Television/NBC, 1966-1969.

Stedman, Eric. n.d. "About the Serial Squadron Archive." The Serial Squadron Cinema Cliffhanger Archive. Accessed December 11, 2016. www.serialsquadron.com/about/.

Stedman, Raymond William. 1971. The Serials: Suspense and Drama by Instalment. Norman: University of Oklahoma Press.

Superman. Dir. Spencer Gordon Bennett and Thomas Carr. Perf. Kirk Alyn, Noel Neill, Herbert Rawlinson. Columbia, 1948.

Telotte, J.P. 1995. Replications: A Robotic History of the Science Fiction Film. Urbana and Chicago: University of Illinois Press.

The Adventures of Fu Manchu. Dir. Franklin Adreon, William Witney. Perf. Clark Howat, Glen Gordon, Lester Matthews. Hollywood Television Services/NBC, 1956.

The Chinatown Mystery. Dir. J. P. McGowan. Perf. Joe Bonomo, Francis Ford, Ruth Hiatt. Syndicate, 1928.

The Flame Fighter. Dir. Robert Dillon. Perf. Jerome La Grasse, Branda Lane, Herbert Rawlinson. Beacon Productions, 1925 .

The House of Hate. Dir. George B. Seitz. Perf. John Webb Dillon, Antonio Moreno, Pearl White. Astra/Pathe, 1918.

The Lone Ranger. Dir. William Witney, John English. Perf. Lee Powell, Hal Taliaferro, Chief Thundercloud. Republic, 1938.

The Phantom Empire. Dir. Otto Brower and Breezy Eason. Perf. Gene Autry, Frankie Darro, Betsy King Ross. Mascot, 1935 . 
The Power God. Dir. Francis Ford. Perf. Al Ernest Garcia, Neva Gerber, Ben Wilson. Ben Wilson/ Goodwill, 1925 .

The Tiger's Shadow. Dir. Spencer Gordon Bennett. Perf. Hugh Allan, Frank Lackteen, Gladys McConnell. Pathe, 1928.

Williams, Raymond. 2004. Television: Technology and Cultural Form. London and New York: Routledge. 